\title{
Draught Requirements of Tillage Tines in Clay Soil under Indoor Soil Bin Conditions
}

\author{
Ajayi F. I*, Yessoufou M. A. and Akinbayo T. E. \\ Department of Agricultural and Environmental Engineering, Federal University of Technology, \\ Akure, Nigeria \\ *Correspondence to: ajayiferanmi22@gmail.com
}

\begin{abstract}
Large tine $(T l)$ and sweep tine $(T w)$ were the different model tillage tines used for this research. The blades were used on clay soil in a soil bin of dimension $9.0 \times 0.85 \times 0.5 \mathrm{~m}$ located in the Department of Agricultural Engineering of the Federal University of Technology, Akure, Nigeria. The clay soil used for the experiment was obtained from Agricultural Engineering Step B Farm. The objective of this study was to evaluate the draught requirements of the model tillage tools and to evaluate and model the parameters of the soil profile produced under different operating conditions. It involved testing and evaluation of tool shape, depth $(12.5-100 \mathrm{~mm})$ and rake angles $\left(30^{\circ}, 45^{\circ}\right.$, and $\left.90^{\circ}\right)$ and forward speed $(0.17 \mathrm{~m} / \mathrm{sec})$ on draught force. Soil profile patterns measured by a profilometer was analyzed using the following parameters - maximum Width of soil cut (Wfs), Ridge-to- Ridge Distance (RRD), furrow depth (df), height of ridge (Hr), maximum Width of Soil Throw (TDW) and tool width (w). Results showed that draught is directly proportional to the depth of the tine at a certain rake angle. The $T w$ had the least draught while $T l$ had the highest draught. Analysis of soil disturbance parameters revealed an increase in parameters with increasing cone index and depth of the tines. The study provides relevant data in the design of soil engaging tools and sustainable crop production.
\end{abstract}

Keywords: Draught, Clay, Soil disturbance, Tillage, Tines.

\section{INTRODUCTION}

Agricultural mechanization may be explained as the farm equipment and the techniques associated with its use, and to others, it is synonymous with tractorization which also encompasses the use of farm equipment including the power sources that are used to operate the various machines (Kaul and Egbo, 1992). One of the important agricultural mechanization processes is tillage. It is the mechanical manipulation of soil to provide favourable conditions for the planting of crops. It involves the soil movement, pulverization, inversion, loosening, cutting, conversion and shearing. William and Glen (1968) list the common objectives of tillage below as (i) conditioning of soil; (ii) eradication or control of plants or plant materials; (iii) establishment of soil boundaries and surface configurations and (iv) incorporating, covering, or handling foreign materials in the soil. Research has highlighted that soiltool-tillage complexes need to be studied for a given location and the tool geometry needs also to be studied to optimize tool performance and energy (Shinde et al., 2011). Another research hinted that 
one of the important parameters for performance evaluation of these tools is soil disruption, it depends on the type of soil, depth, speed of operation and design of tine on which they are mounted (Raper and Sharma, 2004).

While tillage tools may have fixed shapes, their geometrical relations with the soil they contact may be altered with respect to the surface of the soil, and to their direction of travel and mode of operation. As a consequence, the forces applied to the soil by the tool may vary considerably as does the soil reaction. This shows that soil-tillage tool mechanics must be based on quantitative descriptions of the forces applied by the tool and the resulting physical behaviour of the soil (William and Glen, 1968).

Tillage tine provides traction. It is the ability of the vehicle's tractive element to generate enough forces to overcome all types of vehicle resisting forces and hence keep the vehicle in constant travel (Ani et al., 2014). Interaction between vehicle and terrain is achieved through the running gear system, which produces reaction and responses at the terrain interface. For optimum mobility to occur, it is required that the vehicle be able to move from one point to another with a minimum amount of motion loss and energy input. To achieve this, the terrain must provide floatation as well as resistance capability such that enough thrust can be developed between the running gear contact element and terrain material itself with minimal wheel slippage. The greater the ability of the terrain material and the interactions at the interface to transfer the thrust action into the substrate, the better the capability of the vehicle to achieve maximum tractive efficiency (Ani et al., 2014).

Soil tool tests are usually determined using experimental methods. The tests are conducted either on soil bin found in indoor testing facilities or by performing real field testing (outdoor testing) Ani et al. (2014). Usually, the soil parameters in soil bins such as variation of cone index and soil compaction level are more constant (Mardani et al. (2010). Soil bin infrastructural test facility is a sine qua non for studying soil-machine systems. Soil bin facility generally consists but not limited to soil bin, tool carriage, soil processing equipment (soil leveller, compaction roller, rotary tiller), drive system, instrumentation, control and data acquisition systems (Manuwa et al.,2010).

This study experimented terra-mechanics (specifically the interaction of the soil with tillage tools) between tillage tines and clay soil. Clay minerals are formed more usually by chemical changes to produce new minerals such as kaolinite, illite, chlorite, vermiculite, montmorillonite and others. These new minerals tend to break easily into small (less than $0.002 \mathrm{~mm}$ ) sized particles and have rather chemically active surfaces, as well as a large surface area per unit mass (Guggenheim,1990). In the use of this experiment, many soil conditions are avoided such as the effect of the direct impact of sunlight radiation and rainfall effect, because the rainfall duration and intensity and sunlight radiation can be avoided therefore the indoor soil bin can be calibrated to the wanted condition especially the soil moisture content which can affect the soil the plasticity and the cone index characteristics of the soil (Manuwa et al. (2010).

Makanga et al., (1996) carried out a study in a laboratory glass-sided soil bin with dry compact loam soil $(\mathrm{C}=0.02 \mathrm{kPa}, \Phi=200$ and cone index $210 \mathrm{kPa})$ with the specific objective of observing the effect of tine rake angle and aspect ratio on soil failure patterns in dry loam soil. In this study, the tine was moved in the soil in a quasi-static condition and soil failure patterns were observed through a glass window. Tine rake angles of 500, 900, and 1300 were used while aspect ratio effects were studied by varying both width and depth of the tine. Individual effects of width and depth were investigated by maintaining a constant aspect ratio of 2.0 but varying width and depth. The results 
obtained indicated that soil failure patterns are affected by tine design parameters. Soil failure patterns were also observed to be of a progressive shear-type in all cases.

Ali et al., (2013) carried out a study on evaluation and measurement of the performance parameters of agricultural wheels. In this study, a single-wheel tester was designed, constructed and evaluated inside a soil bin. The tested wheel was directly driven by the electric motor. A vertical load was applied by a power bolt-on wheel. This tester can measure required draft force, the depth of tire sinkage, the contact area between wheel and soil, and soil stress at different depths and in both alongside and perpendicular to the direction of traversing. In order to evaluate the system preparation, traction force was measured by the connected S-shaped load cell as arms between the wheel-tester and carriage.

Manuwa and Ademosun (2007) carried out soil bin investigations to study the influence of some soil parameters: moisture content and cone index, on draught force and soil disturbance of model tillage tools. The tools were tines in the groups of very narrow tines, narrow tines and wide tines. The soil under study was a sandy clay loam. It was observed that draught increased at a decreasing rate as the soil moisture content increased from 11 to $22.5 \%$ (db). Polynomial regression models best described the relationships with high $\mathrm{R}^{2}$ (coefficient of determination) values. Soil disturbance parameters: ridge-to-ridge distance, the width of crescent or width of the furrow at the surface, total disturbed width, the height of the ridge, and furrow depth were determined. Tine draught increased at an increasing rate as compaction increased for a cone index in the range of 150 to $800 \mathrm{kPa}$ with polynomial regression equations best describing the relationships. The models generated in this study were suitable for predictive purposes.

The research was aimed at the determination of the draught requirements of tillage tines in clay soil in an indoor soil bin facility. Specifically, this work enabled us to (i) evaluate the draught of model tillage blades on clay soil in a soil bin facility and (ii) determine effect of tools, operational and soil parameters on draught and soil disturbance.

\section{METHODOLOGY}

\section{Study Area and Sampling}

The study was conducted in the Soil Tillage Dynamics Research Laboratory of the Department of Agricultural Engineering of the Federal University of Technology, Akure, Nigeria.

The clay soil used for the experiment was obtained from Agricultural Engineering Step B Farm of the Federal University of Technology, Akure, Nigeria. $7^{0} 30^{1} \mathrm{~N}, 5^{0} 15^{1} \mathrm{E}$, with a land area of about $2,303 \mathrm{~km}^{2}$ and situated within the western upland area. The area has a general elevation of between 300 and 700 meters above the mean sea level and means annual rainfall between $1300 \mathrm{~mm}$ to 1500 $\mathrm{mm}$.

Pit sampling method was used in collecting the sample. It was done by using farm tools (digger, spade, cutlass, and hand trowel) to collect the soil sample through the soil profile. During the collection of this sample, the outermost layer of the soil (about a depth of $5 \mathrm{~cm}$ ) was removed. Then, the soil was dug in profiles such that five profiles $(10 \mathrm{~cm}$ of increasing depth each) of soil were collected. 
Ajayi F.I., Yessoufou M.A. and Akinbayo T.E. (2020): Draught Requirements of Tillage Tines in Clay Soil under Indoor Soil Bin Conditions

\section{Experimental Tillage Tines}

Two tines were used in this study, $\mathrm{T}_{\mathrm{L}}$ (large tine) and $\mathrm{T}_{\mathrm{W}}$ (wide tine) as shown in figures 1 and 2 . The tines were made from a metallic plate made of mild steel, $T_{L}$ was designed to be $10 \mathrm{~mm}$ thick, 450 $\mathrm{mm}$ long and $50 \mathrm{~mm}$ wide with a penetrating width of $25 \mathrm{~mm}$. TW was designed in an arrow form (sweep tine) with a dimension of 50mm width, $300 \mathrm{~mm}$ long and $8 \mathrm{~mm}$ thickness. The upper part of $\mathrm{T}_{\mathrm{L}}$ is $300 \mathrm{~mm}$ long and $50 \mathrm{~mm}$ width, the penetrating part of the tool had a length of $150 \mathrm{~mm}$ to the base of the tool.

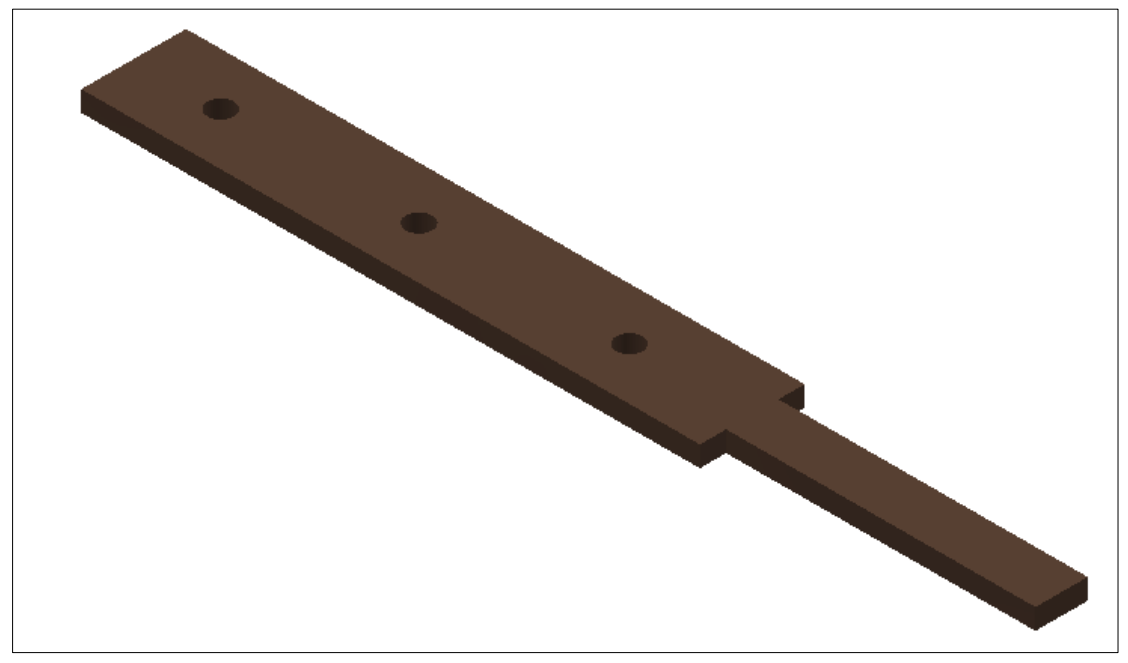

Figure 1: Isometric view of large tine $\left(\mathrm{T}_{\mathrm{L}}\right)$

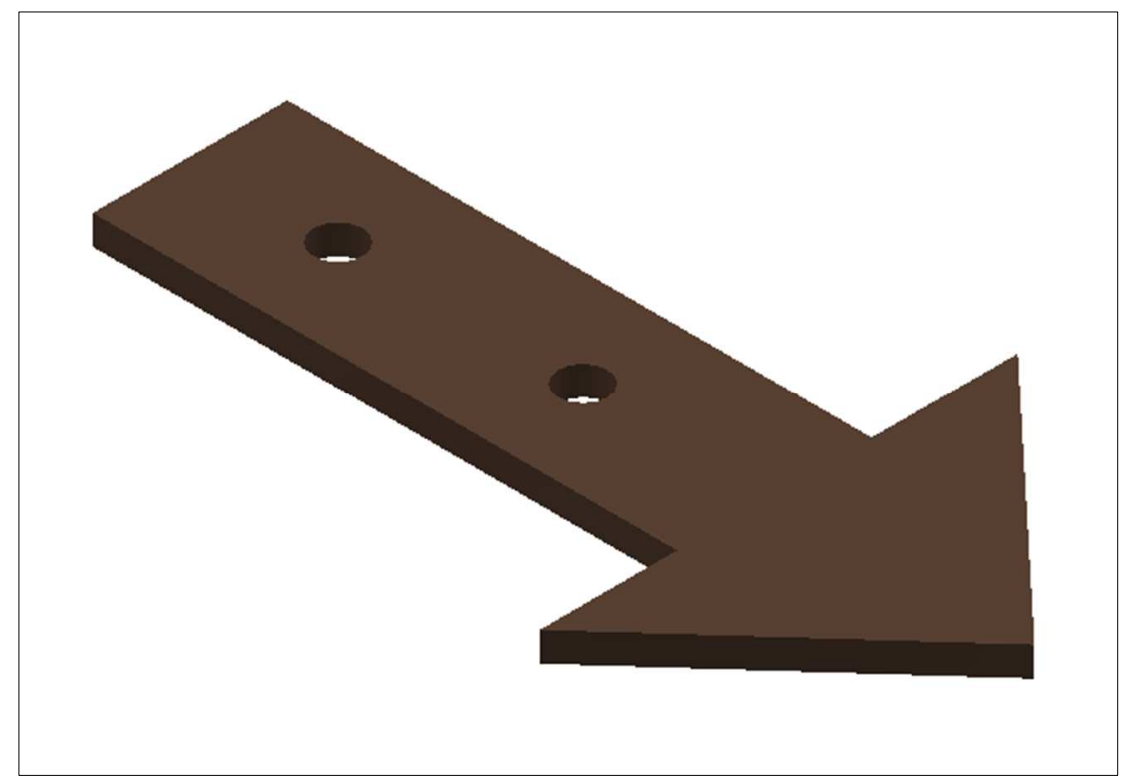

Figure 2: Isometric view of the sweep tine (Tw). 


\section{Soil Bin Facility}

The experiments were conducted in Soil Dynamics Laboratory, Department of Agricultural and Environmental Engineering at The Federal University of Technology, Akure, Nigeria.

An indoor soil bin of dimensions of $9.0 \times 0.85 \times 0.5 \mathrm{~m}$ length, width and height respectively was used. The soil bin consisted of: a load meter; tool carriage; tool vertical adjustment device; tool angle measuring plate; toolbar; profilometer; soil processing trolley frame; soil leveler; compaction roller; Roller vertical adjustment device; Vertical adjustment pipe and; Winding handle. The features of the overhead gantry were the stand, consisting of four legs; the runway; the rails; rack and pinion; reduction gear box; pulleys; chain hoist; electric motors (two) the trolley and the electrical system control unit (Manuwa, 2007).

\section{Experimental Procedure}

\section{Soil preparation and measurement}

The experimental soil bin was filled with clay, the dry moisture content of the soil was less than $3 \%$ DMC which can be considered as a dehydrated soil. The soil was conditioned with $7819 \mathrm{~m}^{3}$ of water. The wet soil was having a moisture content at the dry basis of $31.6 \%$ at $5 \mathrm{~cm}$ depth, $28 \%$ at $10 \mathrm{~cm}$ depth and $3.6 \%$ at $15 \mathrm{~cm}$ depth. The compacted soil in the bin was first tested, to determine the resistivity of the soil to penetration by using a penetrometer (Olubanjo and Yessoufou, 2019). After the test, the mean penetration resistant value for the depth measured was $377.1 \mathrm{~N} / \mathrm{mm}^{2}$ for $5 \mathrm{~cm}$ deep and $2465.6 \mathrm{~N} / \mathrm{mm}^{2}$ for $10 \mathrm{~cm}$ deep for the dry basis. In wet basis, mean penetration resistant value was $3516.9 \mathrm{~N} / \mathrm{mm}^{2}$ for the $5 \mathrm{~cm}$ depth and $3770.9 \mathrm{~N} / \mathrm{mm}^{2}$ for the $10 \mathrm{~cm}$ depth.

After determining the use of the penetration resistance, the leveler and the compactor were used to grade and to compact the soil before and after each procedure.

\section{Test Procedure}

The tine in each case was attached to the tool bar on the carriage and adjustment made to give the required rake angle of $30^{\circ}, 45^{\circ}, 60^{\circ}$ for both tine and depths of operation having $12 \mathrm{~mm}, 25 \mathrm{~mm}, 50$ $\mathrm{mm}$ and $100 \mathrm{~mm}$ for the $\mathrm{T}_{\mathrm{L}}$ tine and $50 \mathrm{~mm}$ and $100 \mathrm{~mm}$ for the $\mathrm{Tw}$ tine. The carriage was then winched from the starting point at a constant linear speed of $0.17 \mathrm{~m} / \mathrm{sec}$ by operating the starting switch from the power unit. The angular speed of the shaft $(150 \mathrm{rpm})$ was measured using a tachometer. The diameter of the driven shaft was measured with a Vernier caliper as $0.0215 \mathrm{~m}$. Thus, angular speed was converted to the linear speed of $0.17 \mathrm{~m} / \mathrm{sec}$ using the formula:

Table 1: Independent and dependent parameters to be measured

\begin{tabular}{|c|c|c|}
\hline $\begin{array}{l}\text { Independent } \\
\text { parameters }\end{array}$ & Levels & Dependent parameters \\
\hline \multirow[t]{2}{*}{ Tools } & $\mathrm{T}_{\mathrm{L}}$ (Large tine) & Draught \\
\hline & Tw (Sweep tine) & $\begin{array}{l}2 . \quad \text { Soil disturbance } \\
\text { parameters (TDW, RRD, HR, DF, } \\
\text { WFS) }\end{array}$ \\
\hline Operating speed & $0.71 \mathrm{~m}$ per sec & \\
\hline \multirow[t]{4}{*}{ Operating depth } & $\mathrm{D}_{1}(12 \mathrm{~mm})$ & \\
\hline & $\mathrm{D}_{2}(25 \mathrm{~mm})$ & \\
\hline & $\mathrm{D}_{3}(50 \mathrm{~mm})$ & \\
\hline & $\mathrm{D}_{4}(100 \mathrm{~mm})$ & \\
\hline
\end{tabular}


$\mathrm{V}=\frac{\pi d n}{60}$

where $\mathrm{v}=$ Linear speed in $\mathrm{m} / \mathrm{sec} ; \mathrm{n}=$ angular speed in $\mathrm{rpm} ; \mathrm{d}=$ diameter of driven shaft

Draught data were collected with a load meter (spring dynamometer) and mean values of three replicates were used for computation and analysis.

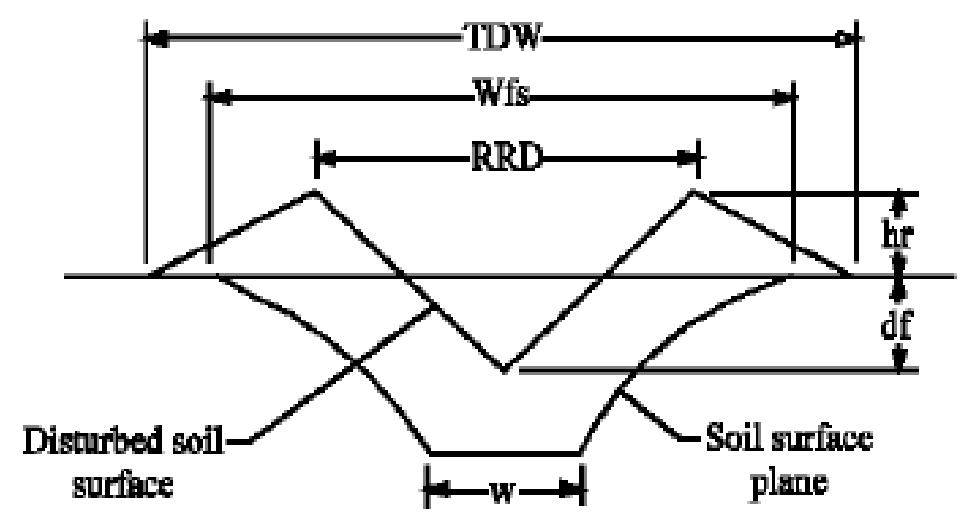

Figure 3: Parameters used to define soil disturbance of a single tillage tool; maximum Width of Soil Throw (TDW); maximum Width of soil cut (Wfs); Ridge-to-Ridge (RRD); the height of ridge (hr); furrow depth (df); tool width (w). (Manuwa, 2007).

\section{RESULTS AND DISCUSSION}

\section{Soil Analysis}

The results of the analysis of the experimental soil are summarized in tables 2 and 3. The soil was classified as clay according to USDA soil textural class with $24 \%$ sand, $58.8 \%$ clay and $17.2 \%$ silt. Compared to other soil profile level, SPL of $0-10 \mathrm{~cm}$ displayed a dark red because of the high presence of organic content in the soil.

Table 2: Textural properties of the experimental soil

\begin{tabular}{l|llll}
\hline S.P.L $(\mathrm{cm})$ & Sand $(\%)$ & Clay $(\%)$ & Silt & Texture $(\%)$ \\
& & & $(\%)$ \\
\hline $0-10$ & 32.8 & 47.2 & 20.0 & Clay \\
$10-20$ & 20.8 & 55.2 & 24.0 & Clay \\
$20-30$ & 16.8 & 67.2 & 16.0 & Clay \\
$30-40$ & 28.8 & 61.2 & 10.0 & Clay \\
$40-50$ & 20.8 & 63.2 & 16.0 & Clay \\
\hline
\end{tabular}

$*$ S.P.L $=$ Soil Profile Level 
Table 3a: Chemical properties of the experimental soil

\begin{tabular}{l|lllllll}
\hline $\begin{array}{l}\text { S.P.L } \\
(\mathrm{cm})\end{array}$ & $\begin{array}{l}\mathrm{pH} \\
\left(\mathrm{H}_{2} \mathrm{O}\right)\end{array}$ & $\begin{array}{l}\mathrm{OC} \\
(\%)\end{array}$ & $\begin{array}{l}\mathrm{OM} \\
(\%)\end{array}$ & $\begin{array}{l}\mathrm{N} \\
(\%)\end{array}$ & $\begin{array}{l}\mathrm{F} \\
(\mathrm{Mg} / \mathrm{kg})\end{array}$ & $\begin{array}{l}\mathrm{K} \\
(\mathrm{Cmol} / \mathrm{kg})\end{array}$ & $\begin{array}{l}\mathrm{Na} \\
(\mathrm{Cmol} / \mathrm{kg})\end{array}$ \\
\hline $0-10$ & 6.44 & 1.21 & 2.08 & 0.32 & 7.78 & 0.39 & 0.39 \\
$10-20$ & 6.55 & 0.61 & 1.06 & 0.21 & 6.53 & 0.31 & 0.31 \\
$20-30$ & 6.77 & 0.63 & 1.09 & 0.16 & 7.39 & 0.47 & 0.33 \\
$30-40$ & 6.63 & 0.46 & 0.97 & 0.08 & 6.53 & 0.37 & 0.30 \\
$40-50$ & 6.57 & 0.52 & 0.89 & 0.08 & 6.69 & 0.17 & 0.30 \\
\hline
\end{tabular}

*S.P.L = Soil Profile Level; OC= Organic Carbon; OM= Organic Matter

Table 3b: Chemical properties of the experimental soil

\begin{tabular}{l|ccllll}
\hline $\begin{array}{l}\text { S.P.L } \\
(\mathrm{cm})\end{array}$ & $\begin{array}{c}\mathrm{Zn} \\
(\mathrm{Cmol} / \mathrm{kg})\end{array}$ & $\begin{array}{c}\mathrm{Fe} \\
(\mathrm{Cmol} / \mathrm{kg})\end{array}$ & $\begin{array}{l}\mathrm{Cu} \\
(\mathrm{Cmol} / \mathrm{kg})\end{array}$ & $\begin{array}{l}\mathrm{Mn} \\
(\mathrm{Cmol} / \mathrm{kg})\end{array}$ & $\begin{array}{l}\mathrm{Ca} \\
(\mathrm{Cmol} / \mathrm{kg})\end{array}$ & $\begin{array}{l}\mathrm{Mg} \\
(\mathrm{Cmol} / \mathrm{kg})\end{array}$ \\
\hline $0-10$ & 11.21 & 5.22 & 1.74 & 7.40 & 2.40 & 1.0 \\
$10-20$ & 6.58 & 4.95 & 3.10 & 8.60 & 1.50 & 0.6 \\
$20-30$ & 13.66 & 5.11 & 2.62 & 5.30 & 1.50 & 0.7 \\
$30-40$ & 7.66 & 4.69 & 1.94 & 6.10 & 1.50 & 0.7 \\
$40-50$ & 13.22 & 4.50 & 1.62 & 7.20 & 1.80 & 0.8 \\
\hline
\end{tabular}

$*$ S.P.L = Soil Profile Level; OC= Organic Carbon; OM= Organic Matter

\section{Effect of Variation of Shape and Depth on Draught at Different Rake Angle}

Results obtained from the experiment are shown in Table 4 for dry soil and Table 5 for wet soil.

Table 4: Measures the working depth and draught required at a rake angle of $30^{\circ}, 60^{\circ}, 90^{\circ}$ for the dry soil

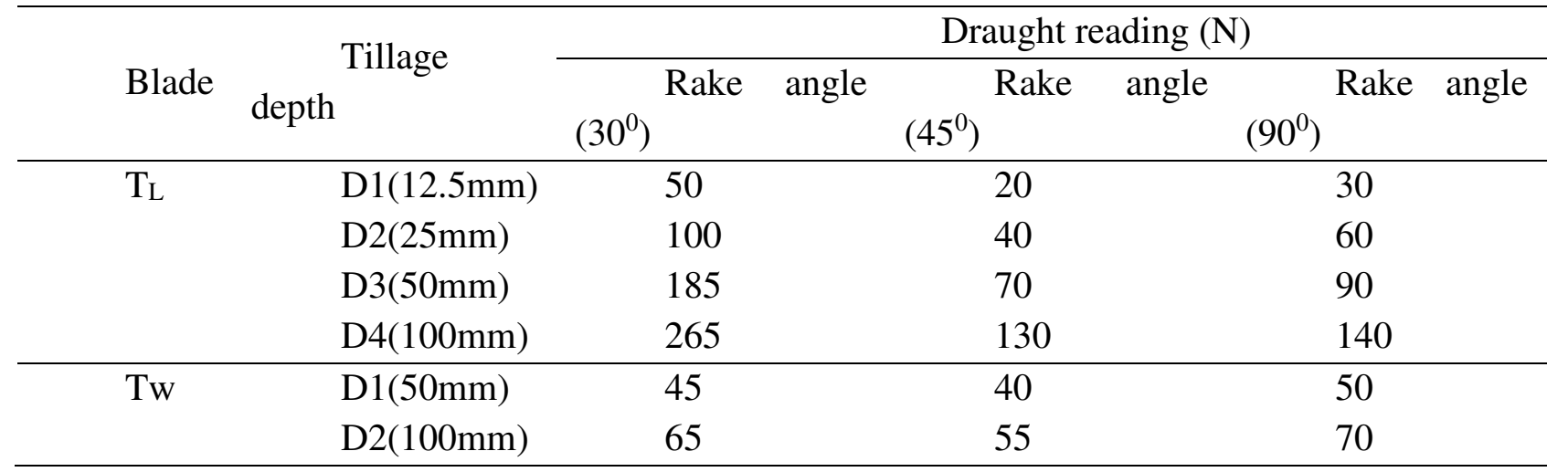


Table 5: $\quad$ Measures the working depth and draught required at rake angle of $30^{\circ}, 60^{\circ}, 90^{\circ}$ for the wet soil

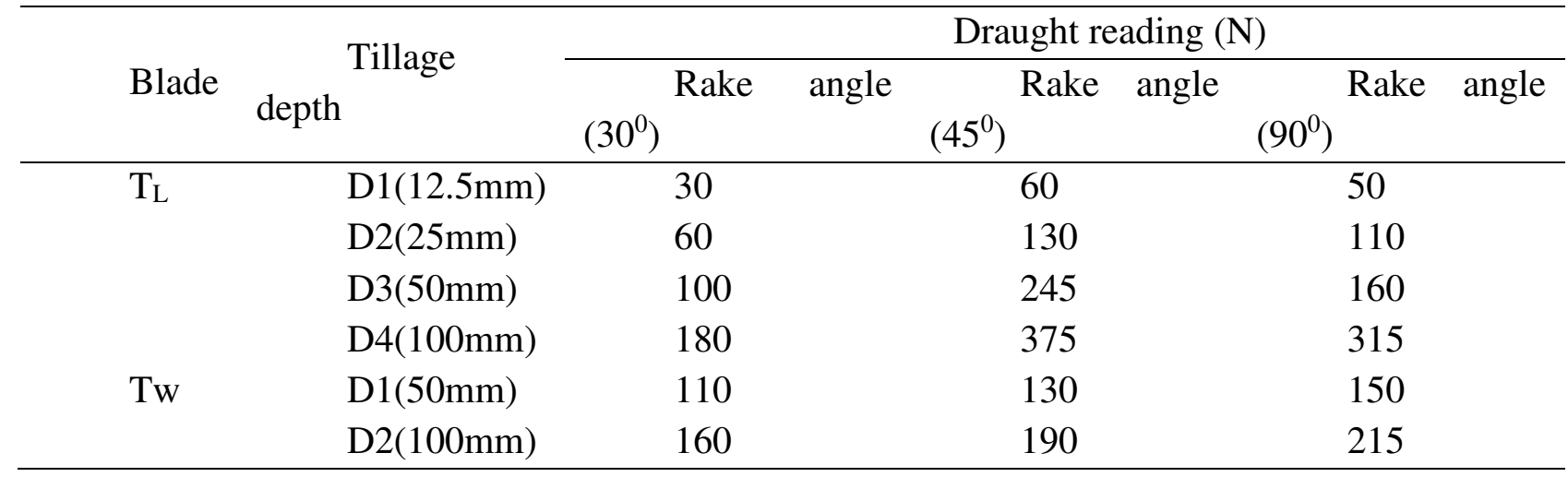

In dry soil, dynamometer reading (draught) increases with increasing depth at a constant rake angle. As the rake angle becomes sharper to the ground (i.e. increasing angle), the higher the force required to draw the tool on the clay soil, such that rake angle at $90^{\circ}$ tends to have the highest required force than other rake angles $\left(30^{\circ}, 45^{\circ}\right)$. It was also noticed that in the dry soil, the force to pull the $30^{\circ}$ tine is greater than that $45^{0}$ degrees while the reverse was observed in the wet soil. It was discussed by Manuwa and Ogunlami (2010) that the variation of draught with a depth of operation was best fitted by a polynomial equation of the second-order (quadratic) with a very high coefficient of determination $\left(\mathrm{R}^{2}\right)$.

In the wet soil, there is a significant difference between the draught required to pull the soil, the force required at $30^{\circ}$ was less than that required at $90^{\circ}$. Also, an increase in the rake angle causes an increase in the draught. The presence of the moisture in the clay soil allows the formation of clod as the tillage tine is in operation, which subsequently makes it hard for the tool to move within the soil structure allowing the penetration power to increase. This could because the adhesive force in the wet soils is higher than dry soil. The decrease in draught with moisture content as discussed by Ademosun (1990) for a sandy loam soil, occurred in the region where the maximum cohesion of the soil had been overcome by water molecules.

Since the best most preferred tillage tines angles are the $90^{\circ}$ and $45^{\circ}$. It was observed that the draught was lower for the $45^{\circ}$ rake angle than for $90^{\circ}$ rake angle. This is in agreement with the observation reported by Manuwa and Ademosun (2007).

The observed draught in $T_{L}$ is consistently more than in $T w$, this difference in draught values may be because $T_{W}$ do not have enough length to resist the forward thrust impounded by the power source, thus the pulling of the soil become difficult with $\mathrm{T}_{\mathrm{L}}$ especially when the depth is high.

The highest value of $\mathrm{R}^{2}$ will consider the most suitable model for predictive determinations. Table 6 and 7 shows the coefficient of determinant using polynomial, logarithmic and exponential models. 
Table 6: Coefficient of determinant $\mathrm{R}^{2}$ equation for large tine $\left(\mathrm{T}_{\mathrm{L}}\right)$ for the dry soil

\begin{tabular}{llll}
\hline Rack angle & Polynomial & Logarithmic & Exponential \\
\hline $30^{\circ}$ & 0.9999 & 0.9887 & 0.8321 \\
$45^{\circ}$ & 0.9941 & 0.9941 & 0.9066 \\
$90^{\circ}$ & 0.9993 & 0.9818 & 0.8518 \\
\hline
\end{tabular}

Table 7: Coefficient of determinant $\mathrm{R}^{2}$ equation for large tine $\left(\mathrm{T}_{\mathrm{L}}\right)$ for wet soil

\begin{tabular}{llll}
\hline Rake angle & Polynomial & Logarithmic & Exponential \\
\hline $30^{\circ}$ & 0.9984 & 0.9971 & 0.8989 \\
$45^{\circ}$ & 1 & 0.9245 & 0.8924 \\
$90^{\circ}$ & 0.9906 & 0.9835 & 0.8388 \\
\hline
\end{tabular}

From the extrapolated data, while considering the range of soil condition. It was observed that that the polynomial model presented the most suitable values, showing that the draught increased with the increase in cone index of the clay soil in agreement with Manuwa and Ogunlami (2010) who reported that the variation of draught with the depth of operation was the best fitted by a polynomial equation of the second-order (quadratic) with a remarkably high coefficient of determination $\left(\mathrm{R}^{2}\right)$.

\section{Effect of Blade Shape on Soil Disturbance Parameters on a Wet Soil}

A lab experiment was carried out to evaluate the effect of the shape of the blade on soil disturbance. Soil parameters such as RRD (Ridge-to-Ridge Distance), WFs (maximum Width of soil cut), TDW (maximum Width of Soil Throw), Hr (height of ridge) and Df (furrow depth) were measured for both tines $\left(\mathrm{T}_{\mathrm{L}}\right.$ and $\left.\mathrm{T}_{\mathrm{w}}\right)$ at $30^{\circ}, 45^{\circ}$ and $90^{\circ}$ to the soil and at varying depth $(12.5 \mathrm{~mm}, 25 \mathrm{~mm}, 50 \mathrm{~mm}$ and $100 \mathrm{~mm}$ for $\mathrm{T}_{\mathrm{L}} ; 50 \mathrm{~mm}$ and $100 \mathrm{~mm}$ for $\mathrm{T}_{\mathrm{W}}$ ). The results obtained from the soil disturbance experiment are shown in table 8, 9, 10 and illustrated in figure 4.

Table 8: Soil disturbance parameters for $30^{\circ}$ degree on the wet soil

\begin{tabular}{ccccccc}
\hline \multirow{2}{*}{ Tool $\begin{array}{c}\text { Tillage } \\
\text { Depth }\end{array}$} & \multicolumn{5}{|c}{ Soil disturbance parameter } \\
\cline { 3 - 7 }$(\mathrm{mm})$ & $\begin{array}{l}\text { RRD } \\
(\mathrm{mm})\end{array}$ & $\begin{array}{l}\text { TDW } \\
(\mathrm{mm})\end{array}$ & $\begin{array}{l}\text { HR } \\
(\mathrm{mm})\end{array}$ & $\begin{array}{l}\text { DF } \\
(\mathrm{mm})\end{array}$ & $\begin{array}{l}\text { WFs } \\
(\mathrm{mm})\end{array}$ \\
\hline \multirow{3}{*}{$\mathrm{T}_{\mathrm{L}}$} & 12.5 & 30 & 43 & 15 & 10 & 20 \\
& 25 & 38 & 61 & 25 & 30 & 30 \\
& 50 & 69 & 134 & 35 & 30 & 60 \\
& 100 & 73 & 140 & 40 & 70 & 65 \\
\hline \multirow{2}{*}{$\mathrm{T}_{\mathrm{W}}$} & 50 & 112 & 230 & 30 & 20 & 110 \\
& 100 & 94 & 190 & 40 & 40 & 85 \\
\hline
\end{tabular}

RRD (Ridge-to- Ridge Distance), WFs (maximum Width of soil cut), TDW (maximum Width of Soil Throw), HR (height of ridge) and Df (furrow depth) 
Table 9: Soil disturbance parameters for $45^{\circ}$ degree on the wet soil

\begin{tabular}{ccc|cccc}
\hline \multirow{2}{*}{ Tool } & \multirow{2}{*}{$\begin{array}{c}\text { Tillage } \\
\text { Depth }\end{array}$} & \multicolumn{5}{|c}{ Soil disturbance parameter } \\
\cline { 3 - 7 }$(\mathrm{mm})$ & $\begin{array}{l}\text { RRD } \\
(\mathrm{mm})\end{array}$ & $\begin{array}{l}\text { TDW } \\
(\mathrm{mm})\end{array}$ & $\begin{array}{l}\text { HR } \\
(\mathrm{mm})\end{array}$ & $\begin{array}{l}\text { DF } \\
(\mathrm{mm})\end{array}$ & $\begin{array}{l}\text { WFs } \\
(\mathrm{mm})\end{array}$ \\
\hline \multirow{2}{*}{$\mathrm{T}_{\mathrm{L}}$} & 12.5 & 50 & 72 & 15 & 15 & 35 \\
& 25 & 85 & 130 & 25 & 25 & 60 \\
& 50 & 115 & 179 & 55 & 50 & 85 \\
& 100 & 155 & 205 & 65 & 80 & 100 \\
\hline \multirow{2}{*}{$\mathrm{T}_{\mathrm{W}}$} & 50 & 80 & 126 & 30 & 20 & 60 \\
& 100 & 180 & 240 & 35 & 40 & 110 \\
\hline
\end{tabular}

RRD (Ridge-to- Ridge Distance), WFs (maximum Width of soil cut), TDW (maximum Width of Soil Throw), HR (height of ridge) and Df (furrow depth)

Table 10: Soil disturbance parameters for $90^{\circ}$ degree on the wet soil

\begin{tabular}{ccccccc}
\hline \multirow{2}{*}{ Tool Tillage } & \multicolumn{5}{|c}{ Soil disturbance parameter } \\
\cline { 3 - 7 } & $\begin{array}{c}\text { Depth } \\
(\mathrm{mm})\end{array}$ & $\begin{array}{l}\text { RRD } \\
(\mathrm{mm})\end{array}$ & $\begin{array}{l}\text { TDW } \\
(\mathrm{mm})\end{array}$ & $\begin{array}{l}\text { HR } \\
(\mathrm{mm})\end{array}$ & $\begin{array}{l}\text { DF } \\
(\mathrm{mm})\end{array}$ & $\begin{array}{l}\text { WFs } \\
(\mathrm{mm})\end{array}$ \\
\hline \multirow{3}{*}{$\mathrm{T}_{\mathrm{L}}$} & 12.5 & 62 & 90 & 20 & 17 & 40 \\
& 25 & 90 & 130 & 45 & 23 & 60 \\
& 50 & 130 & 190 & 60 & 50 & 90 \\
& 100 & 176 & 230 & 60 & 80 & 110 \\
\hline \multirow{2}{*}{$\mathrm{T}_{\mathrm{W}}$} & 50 & 95 & 125 & 40 & 20 & 60 \\
& 100 & 188 & 220 & 45 & 40 & 110 \\
\hline
\end{tabular}

RRD (Ridge-to- Ridge Distance), WFs (maximum Width of soil cut), TDW (maximum Width of Soil Throw), HR (height of ridge) and DF (furrow depth)

It was observed from the experiment that the $\mathrm{T}_{\mathrm{L}}$ and the $\mathrm{T}_{\mathrm{W}}$ displayed an increase in soil disturbance parameter with increasing depth (Table 8, 9 and 10). For both tines, the soil disturbance parameter was increasing with the increase in the cone index and depth of the tines. In contrast with other soil disturbance parameters, the height of ridge parameter for the $T_{W}$ seems to be decreasing as the depth increases, this is due to the increase in the mechanical property of the soil as the cone index increases in agreement with Manuwa and Ademosun (2007).

$\mathrm{T}_{\mathrm{L}}$ was more effective in developing soil with higher HR and DF, especially when positioned at an angle of $90^{\circ}$ to the soil. The soil disturbance at $\mathrm{T}_{\mathrm{W}}$ at $90^{\circ}$ can be said to be the most satisfying because it creates the best soil formation and the draught required is minimal compared to $\mathrm{T}_{\mathrm{L}}$ at $90^{0}$, a similar observation was reported by Manuwa (2010). 


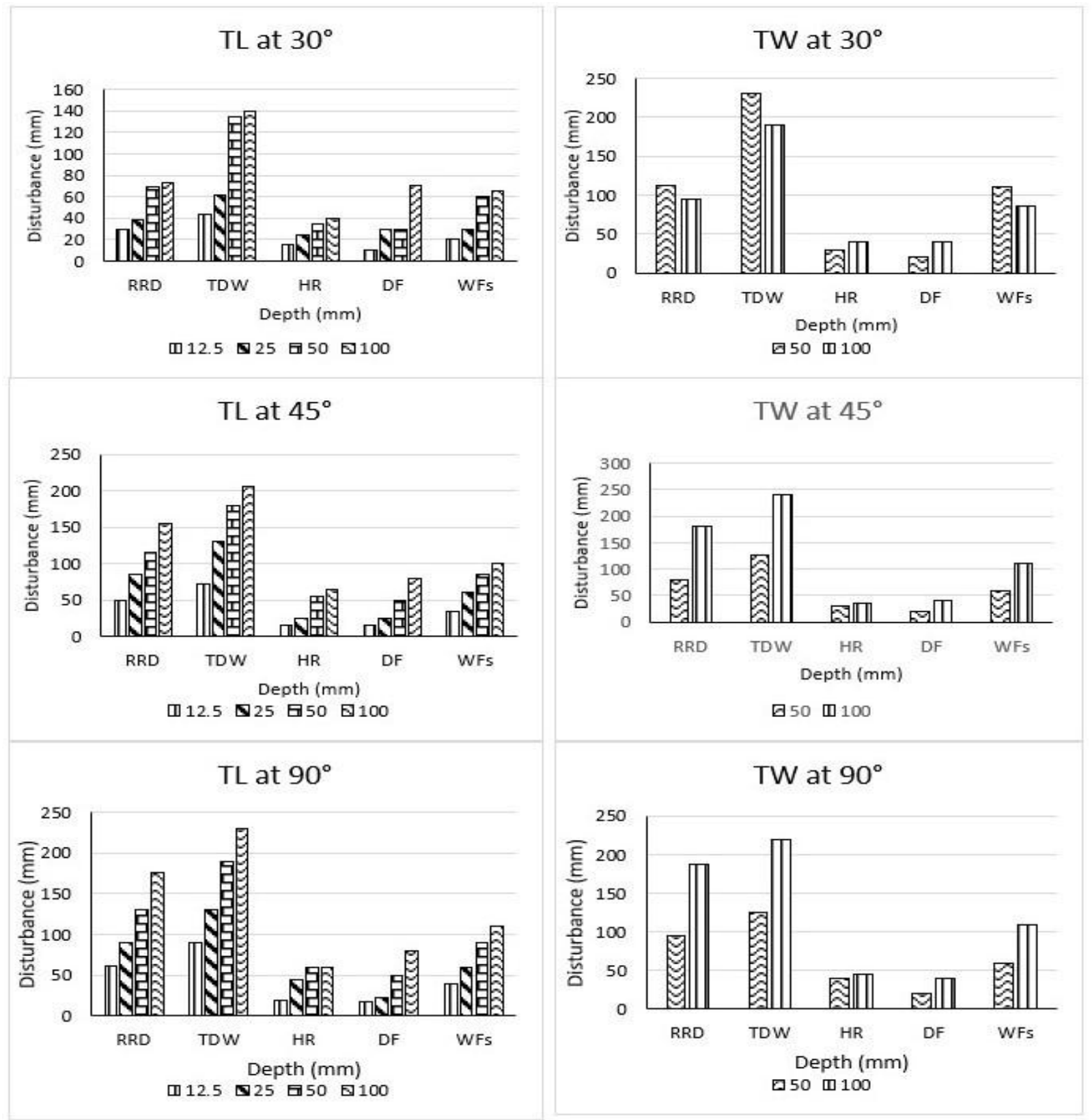

Figure 4: Disturbance parameter for TL and TW at various degrees and various depths.

\section{CONCLUSIONS}

Draught and soil profile parameters of two different model tillage blades: large tine $\left(\mathrm{T}_{\mathrm{L}}\right)$, sweep time (Tw), were investigated in an indoor soil bin containing clay soil. The large tine $\left(\mathrm{T}_{\mathrm{L}}\right)$ was having higher draught than the sweep tine (Tw), although the sweep tine Tw is having larger disturbance parameters than the large tine $\left(\mathrm{T}_{\mathrm{L}}\right)$. The different shapes produce different geometries of the soil profile. The parameters of the soil profile were affected by the depth of operation.

\section{REFERENCES}

[1] Kaul R. N and C.O. Egbo (1992). Introduction to Agricultural Mechanization. Macmillan Press Ltd. London, P. 79. 
[2] Raper, R. L., \& Sharma, A. K. (2004). Soil moisture effects on energy requirements and soil disruption of subsoiling a coastal plain soil. Transactions of the ASAE, 47(6), 1899.

[3] William, R., Berg, G. E. V., \& Gill, W. R. (1968). MECHANICS OF TILLAGE TOOLS. In Soil Dynamics (p. 117). American Society of Agricultural and Biological Engineers.

[4] Ani A. O., Uzoejinwa B. B., Ezeama A. O., Ugwu S. N., Ohagwu C. J. and Odigboh E. U. (2014) Soil Bin Facility for Soil-machine Interaction Studies. Department of Agricultural and Bioresources Engineering, University of Nigeria, Nsukka. Proceedings of the International Soil Tillage Research Organisation (ISTRO) Nigeria Symposium, Akure 2014 November 3 - 6, Akure, Nigeria Soil Bin Facility for Soil-machine Interaction Studies. 110 - 124.

[5] Mardani, A., Shahidi, K., Rahmani, A., Mashoofi, B and Karimmaslak, H. (2010). Studies on a Long Soil Bin for Soil-Tool Interaction. Department of Agricultural Machinery, Urmia University, Iran.CercetăriAgronomiceîn Moldova Vol. XLIII. No. 2 (142) / 2010.

[6] Manuwa, S.I., and Ogunlami, M.O. (2010). Soil-Tool Interaction Modelling of Parameters of Soil Profile Produced by Tillage Tools. Journal of Engineering and Applied Sciences 5(2): 91-95, 2010. ISSN: 1816-949X.

[7] Guggenheim, S (1990). Introduction to the Properties of Clay Soil Minerals.Department of Geological Sciences. The University of Illinois at Chicago. 845 W. Taylor St. Chicago, Illinois 60607-7059.xtal@uic.edu.

[8] Makanga, J.T., Salokhe, V.M., Gee-Clough, D., (1996). Effect of tine rake angle and aspect ratio on soil failure patterns in dry loam soil. J. Terramech. 33 (5) 233- 252.

[9] Manuwa, S. and Ademosun, O.C. (2007). "Draught and Soil Disturbance of Model Tillage Tines under Varying Soil Parameters". Agricultural Engineering International: the CIGR E-journal. Manuscript PM 06 016. Vol. IX. March 2007.

[10] Olubanjo, O. O., \& Yessoufou, M. A. (2019). Effect of Soil Compaction on the Growth and Nutrient Uptake of Zea Mays L. Sustainable Agriculture Research, 8(526-2020-528), 46-54.

[11] Ademosun, O. C. (1990). The design and operation of soil tillage dynamics equipment. The Nigerian Engineer, 25(1), 51-57.

[12] Manuwa, S. I. (2002). Development of equipment for soil tillage dynamics and evaluation of tillage parameters (Doctoral dissertation, Federal University of Technology Akure).

[13] Roozbahani, A., Mardani, A., Jokar, R., \& Taghavifar, H. (2013). Evaluating and measuring the performance parameters of agricultural wheels. World Academy of Science, Engineering and Technology, Int. J. Biol. Biomol. Agr. Food Biotechnol. Eng, 7(2), 158-162.

[14] Shinde, G.U., Badgujar, P.D. and Kajale, S.R. (2011). Experimental Analysis of Tillage Tool Shovel Geometry on Soil Disruption by Speed and depth of operation. 2011 International Conference on Environmental and Agriculture Engineering IPCBEE vol.15 (2011) (C) (2011) IACSIT Press, Singapore. 